whatever quantities it could sell at the going price; the result would be to reinforce the already impressive tendency towards fuel efficiency the past decade has seen, to reinforce the sense of realism that must dawn on OPEC and at the same time to take at least the edge off the horrendous deficit on the trade balance of the United States.

The British case is different. North Sea oil was merely a mirage when OPEC's existence began, but Britain has now become more than self-sufficient. But the circumstances of the United States do not apply. The cost of winning oil from the North Sea is much higher than in Texas or the Middle East, and although there is no reason why oil companies which have already invested in holes in this inhospitable ground should not sell the oil that comes up for what it-will make, falling prices are bound to undercut the incentive for drilling further holes. That is the most durable reason why the past few months of falling oil prices have made the financial markets jittery about the health of the British economy but there is also a more immediate worry, the knowledge that the British government's revenues depend significantly, if only at the margin, on the tax levied on oil production in the North Sea. In the short run, as sterling falls against the dollar, the taxes (calculated in sterling) will not be vulnerable but, further ahead, the prospect that Britain, an oil producer for the past fifteen years, will soon cease to be a potential member of OPEC is bound to scare the international community. One measure of that anxiety is the further increase of 2 per cent in bank lending rates earlier this week - the second such step in ten days. Another is the general sense of unease that five years of a generally rigorous economic strategy have yielded nothing. There must be many in Britain now who wish that the North Sea had proved empty of oil, and that traditional British manufacturing industry had not been decimated by the uncompetitiveness engendered by the brief spell when British oil flowed freely.

\section{Spreading thin}

The British research enterprise wants to spread $£ 4$ million fairly, which is impossible.

THE Royal Society, probably the most reputable means of pulling chestnuts out of fires, has now lent three of its officers (including its president, Sir Andrew Huxley) to what may yet prove a risky cause, that of helping the British University Grants Committee spend a windfall $£ 4$ million on university equipment. The windfall came about at the end of last year, when Sir Keith Joseph, Secretary of State for Education and Science, promised an extra $£ 10$ million for the provision of equipment at universities only to find that, before he could deliver, more than half the money had been snatched away again by the government to which he belongs, on the grounds that the source of the promised funds (the pockets of middle-class parents) was politically a poisoned chalice. So the grants committee is faced with the prospect of distributing a sum of money so small that a single good use could absorb the lot among as many recipients as possible, so as to encourage the notion that fair play is not yet dead. To assist the president of the Royal Society and the physical and biological secretaries thereof, not to mention the chairman of the grants committee and the executive head of the Medical Research Council, there will be seven other distinguished academics. Their task is to pick a dozen research groups in the United Kingdom to which the committee may make a substantial present of equipment.

The obvious danger in the arrangements now in place for distributing what is, after all, a very modest sum of money, is that even this distinguished committee will overlook some worthy cause, a group of talented researchers somewhere whose claims on shrinking public funds are by accident neglected. The contrary risk, that the committee will somehow seize on projects to support whose virtues are more apparent than real, is not serious but cannot be neglected. That is one potential source of risk. It is, however, much more a source of hazard to the public reputation of science and those who manage it in Britain that such a large group of such distinguished people should be engaged in a onceand-for-all attempt to apportion $£ 4$ million among what must be 1,000 legitimate claimants. Especially because the grants committee has set up three separate committees to decide how, and by what criteria, particular university departments should be encouraged over the long run, there is every reason why the members of the extra committee now appointed should have declined to serve, giving the excuse that they had more important things to do.

Unfortunately, this is not how the administration of British science works. When funds are as scarce as they have become, so much so that groups of talented people are at their wits' end to know how they will prosecute their ideas, there is no way in which an extra $f 4$ million can put things right. Yet everybody behaves as if fairness must be demonstrated. So, small though the occasion may be, the committee must be all the more distinguished. Drawing lots would serve as well.

\section{Congress and science}

\section{Congressmen should know some science. US universities are cashing in.}

UNIVERSITY public relations, also known as the art of reflecting glory, took a major step forward several years ago when Harvard University's Kennedy School of Government hit upon the scheme of staging a special seminar on public policy and legislative procedure for newly-elected congressmen. Other universities have since seized upon the concept, recognizing their unique ability to provide such a public service as well as their unique ability, unshared by the National Association of Dredging Contractors, to lobby under the guise of educating.

The latest entry is George Washington University, which last week put on its first Seminar on Science in Government for new members of Congress, a two-day cramming session organized by Mike McCormack, himself a former congressman and now a Washington consultant on science policy. Leading lights of science policy and science-in-society, among them Joshua Lederberg, Lewis Thomas and Leon Lederman, were poised at hourly intervals to brief the dozen or so congressmen who showed up.

First, however, the president of George Washington University reminded the congressmen that if they ever needed technical information, they need only pick up the phone and call George Washington University. The National Academy of Sciences (NAS) representatives (NAS supplied the meeting rooms for the seminar and the accompanying social events) reminded the congressmen that the briefing documents on interesting areas of science prepared by the academy for science adviser George Keyworth were available to them. The representative of the American Society of Mechanical Engineers reminded the congressmen of his group's sponsorship (and origination) of the Congressional Fellows Program, which provides expert mid-career scientists and engineers free of charge as congressional staffers for one year. Mike McCormack reminded the congressmen of the sponsors that made the seminar possible, among them Bechtel, Atlantic Richfieid, Dow Chemical, Monsanto, Stone \& Webster and the US Committee for Energy Awareness.

The congressmen learned the first day that "science does not involve partisan politics"; that "science is not a panacea"; that two-thirds of the world's population lives in poverty; that the build-up of carbon dioxide in the atmosphere and nuclear war threaten mankind's survival; that "there has never been a scientific problem more urgently in need of settling" than that of nuclear winter; that "scientists come in two classes, good ones and not so good ones"; that people with PhDs can be "dumb"; that "predictions can often be wrong, particularly if they're about the future"; that one senator in 1901 complained that he was tired of "all this science" on which millions had already been spent and it was "about time it was stopped"; that the first law of thermodynamics can be derived from symmetry considerations; and that instead of multiplying two factors you can add their logarithms. By then there were only four congressmen left. $\square$ 